\title{
INTERACTIONS BETWEEN THE HERBACEOUS AND SHRUBBY-ARBOREAL COMPONENTS IN A SEMIARID REGION IN THE NORTHEAST OF BRAZIL: COMPETITION OR FACILITATION? ${ }^{1}$
}

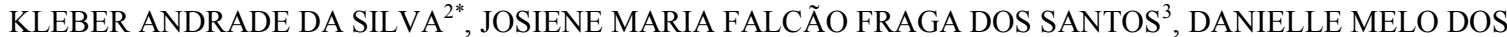 \\ SANTOS $^{3}$, JULIANA RAMOS DE ANDRADE ${ }^{3}$, ELBA MARIA NOGUEIRA FERRAZ $^{4}$, ELCIDA DE LIMA ARAÚJO $^{3}$
}

\begin{abstract}
Under conditions of high stress, interactions between species can be positive. Islands of perennial vegetation can improve the conditions of the understory and facilitate the establishment of herbaceous plants. The hypothesis of this study is that islands of perennial vegetation in an area of caatinga harbor, a greater richness, diversity and density of herbaceous plants, and that individuals reach a greater height and diameter than in open spaces. The study was conducted in Petrolândia, Pernambuco, Brazil. Twenty-seven plots were installed in the center of the islands, 38 at the edge of the islands (in a total of 38 islands) and 35 in the open spaces. A total of 51 species were recorded in the center and 55 on the edge of the islands and 48 in the open spaces. The mean richness of the open spaces was lower than on the islands. The diversity was greater in the center of the island and became less on the edge of the island and in the open spaces. The mean density was lower in the open spaces than on the islands. The mean density at the edge of the islands was greater than in the center of the islands. There was no difference in mean diameter of herbaceous plants. The mean height of the individuals was higher in the center of the islands. The herbaceous community growing on the islands exhibited higher richness, diversity, density and height than in open spaces. Thus, islands of perennial vegetation facilitate the establishment of herbaceous species.
\end{abstract}

Keywords: Caatinga. Microhabitat. Microclimate. Diversity. Structure.

\section{INTERAÇÕES ENTRE OS COMPONENTES HERBACEO E ARBUSTIVO-ARBÓREO EM UMA REGIÃO SEMIÁRIDA NO NORDESTE DO BRASIL: COMPETIÇÃO OU FACILITAÇÃO?}

\begin{abstract}
RESUMO - Em condições de elevado estresse as interações entre espécies podem ser positivas. Ilhas de vegetação perene podem melhorar as condições do sub-bosque e facilitar o estabelecimento de plantas herbáceas. A hipótese deste estudo é que as ilhas de vegetação perene de uma área de caatinga abrigam uma maior riqueza, diversidade, densidade e indivíduos com maior altura e diâmetro do que os espaços abertos. O estudo foi realizado em uma área de caatinga em Petrolândia, Pernambuco, Brasil. Para o levantamento florístico e estrutural (densidade e altura e diâmetro dos indivíduos) das herbáceas, foram instaladas 27 parcelas no centro das ilhas de vegetação lenhosa, 38 na borda das ilhas (em um total de 38 ilhas) e 35 nos espaços abertos. Foram registradas 51 espécies no centro e 55 na borda das ilhas e 48 nas áreas abertas. A riqueza média das áreas abertas foi menor do que a riqueza média das ilhas. A diversidade foi maior no centro das ilhas e diminuiu na borda da ilha e nas áreas abertas. A densidade média foi menor nas áreas abertas do que nas ilhas. A densidade média na borda das ilhas foi maior do que no centro das ilhas. Não houve diferença no diâmetro médio das plantas herbáceas. A altura média dos indivíduos foi maior no centro das ilhas. Neste estudo, a riqueza de espécies, diversidade, densidade e altura da comunidade herbácea instalada nas ilhas foram maiores do que nas áreas abertas. Então, as ilhas de vegetação perene facilitam o estabelecimento das espécies herbáceas.
\end{abstract}

Palavras-chave: Caatinga. Microhabitat. Microclima. Diversidade. Estrutura.

\footnotetext{
${ }^{*}$ Corresponding Author

${ }^{1}$ Received for publication in 21/05/2014; accepted on 30/04/2015.

${ }^{2}$ Laboratório de Biodiversidade, Centro Acadêmico de Vitória, Universidade Federal de Pernambuco (UFPE), 55.608-680, Alto do Reservatório, Vitória de Santo Antão, Pernambuco, Brazil; kleberandradedasilva@hotmail.com.

${ }^{3}$ Laboratório de Ecologia Vegetal dos Ecossistemas Naturais (LEVEN), Departamento de Biologia, Área de Botânica, Universidade Federal Rural de Pernambuco (UFRPE), 52.171-900, Dois Irmãos, Recife, Pernambuco, Brazil.

${ }^{4}$ Instituto Federal de Educação, Ciência e Tecnologia de Pernambuco (IFPE), 50.740-540, Cidade Universitária, Recife, Pernambuco, Brazil.
} 


\section{INTRODUCTION}

Warm arid and semiarid regions are characterized by high temperatures and low rainfall. Therefore, plants that inhabit these regions are subjected to high abiotic stress (ARAÚJO; CASTRO; ALBUQUERQUE, 2007). Under conditions of high stress, interactions between species can be positive (GUREVITCH; SCHEINER; FOX, 2009). In arid and semiarid regions where the community is made up of shrubs and/or trees randomly distributed within a matrix of herbaceous vegetation or bare soil, plant canopies can alter the microclimatic conditions of the understory and play an important role in structuring the community of herbaceous plants (FACELLI; TEMBY, 2002).

The canopy of trees and/or shrubs blocks the sunlight and, consequently, the amount of light that touches the ground decreases significantly from the edge to the center of the shrub canopy (MORO et al., 1997a). In open areas, the sun rays touch the ground directly. Therefore, the microclimate below the canopy is characterized by lower mean temperatures and higher relative humidity when compared to open spaces (TRACOL; GUTIÉRREZ; SQUEO, 2011). Furthermore, the microclimate below the canopy is more constant as a result of a low daily variation in temperature (TRACOL; GUTIÉRREZ; SQUEO, 2011). In addition to microclimatic changes, the shrubs can affect soil properties and nutrient cycling (PUGNAIRE; HAASE; PUIGDEFABREGAS, 1996). Below the canopy, there is a larger amount of organic material and high rate of mineralization. As a result, the soil below the shrub canopy is richer in nutrients (e.g. N, P and total P) (MORO et al., 1997b; FULLER, 1999; ZHAO et al., 2007). These changes in microclimate and soil fertility contribute to the establishment of herbaceous vegetation below the canopy in the beginning stages of regeneration (MORO et al., 1997a; TRACOL; GUTIÉRREZ; SQUEO, 2011). This process where some species may change the abiotic environment and facilitate the establishment of other species is known as facilitation (BEGON; TOWNSEND; HARPER, 2007). Plants are important facilitators in environments with high abiotic stress because they enhance germination, seedling recruitment and growth of seedlings and juveniles in various types of communities (GUREVITCH; SCHEINER; FOX, 2009).

This is indeed true, as several studies indicate that species richness, density and height of individuals in the community of herbaceous plants beneath the shrub canopy are greater than in open areas (PUGNAIRE; HAASE; PUIGDEFABREGAS, 1996; PUGNAIRE; LÁZARO, 2000; FACELLI; TEMBY, 2002; ZHAO et al., 2007). The structure of the shrub canopy can also contribute to the recruitment of woody plants (TRACOL; GUTIÉRREZ; SQUEO, 2011). Thus, shrubs can be treated as islands of woody vegetation embedded in a matrix of herbaceous vegetation or bare soil and can act as islands of resources font for the herbaceous understory community (MACARTHUR; WILSON, 1967).

Most of the warm semiarid region of northeastern Brazil is occupied by vegetation known locally as caatinga (ANDRADE-LIMA, 1981). The caatinga is characterized by having two well defined seasons: 1) rainy season - which lasts three to six months; 2) dry season - which lasts six to nine months. The annual precipitation varies from 252 to $1200 \mathrm{~mm}$, and the rainy season accounts for 80 to $90 \%$ of the total annual rainfall with irregular distribution (SAMPAIO, 1995; ARAÚJO; CASTRO; ALBUQUERQUE, 2007). The caatinga vegetation consists of a mosaic of phytophysiognomies (ANDRADE-LIMA, 1981). Communities located on sedimentary basins may exhibit a phytophysiognomy of islands of woody vegetation immersed in a matrix of bare, sandy soil (ANDRADE-LIMA, 1981). Therefore, these islands can act as a source of resources for the herbaceous understory community. This situation is a good scenario for verifying whether the communities of woody and herbaceous plants growing on the sandy soils of sedimentary basins exhibit competition or facilitation interactions.

Based on the premise that the conditions of microclimate and soil fertility on the islands of vegetation are more favorable to the establishment of a community of herbaceous plants than bare soil matrix, the hypothesis of this study is that, in areas of caatinga with a physiognomy of vegetation islands installed in sedimentary basins, the islands act as refuges for biodiversity, harboring greater species richness, diversity, and density of herbaceous plants, as well as individuals of greater height and diameter. So the aim of this study was to investigate whether there are differences in the richness, diversity and community structure between the herbaceous community installed in the center and on the edge of the shrub-arboreal islands and in areas of matrix devoid of woody vegetation (open spaces), in an area of caatinga located in the Brazilian semiarid.

\section{MATERIAL AND METHODS}

The study was conducted in a Caatinga community in the municipality of Petrolândia, Pernambuco, in the District of Mundo Novo. The area was established on sandy soils in a region of basins and sedimentary coverage $\left(9^{\circ} 04^{\prime} 57^{\prime}, \quad \mathrm{S}\right.$ and $38^{\circ} 13^{\prime} 47^{\prime}$ ' $\mathrm{W}$, at an elevation of $432 \mathrm{~m}$ ). The area is drained by the Salgado Stream, which originates on the Serra do Tacaratu and flows into the São Francisco River (FIAM/DI, 1986), and has a dry and hot local climate, semiarid Bshw classification, with concentrated rains from January to May and an annual rainfall of approximately $435 \mathrm{~mm}$. The average temperature remains close to $25^{\circ} \mathrm{C}$ year round, with $55 \%$ relative humidity and an average annual evaporation of 3,008 mm/year ${ }^{-1}$ (BRASIL, 1983; FIAM/ 
DI, 1986; PERAZZO, 2002). The area has 2 ha and is on private property; the landowners reported that the area selected for this study had not been subject to agricultural or extensive livestock influences for at least 20 years.

In the area, there was practically no superposition of the crowns of woody plants, which resulted in a discontinuous canopy (forming islands of vegetation surrounded by land without woody vegetation) and places with greater penetration of sunlight. The size of these wood vegetation island varies from $6 \mathrm{~m}$ to $12 \mathrm{~m}$ in diameter. The distance between the center and the edge of the islands ranged from $3 \mathrm{~m}$ to $6 \mathrm{~m}$. Jatropha mollissima (Pohl) Baill. and J. ribifolia (Pohl) Baill. were most abundant. In general, the woody flora of the area was characterized by the presence of species such as Amburana cearensis (Allemão) A.C. Sm, Anadenanthera colubrina (Vell.) Brenan, Aspidosperma pyrifolium Mart., Bauhinia cheilantha (Bong.) Steud., Cereus jamacaru DC., Caesalpinia microphylla Buch.-Ham., Cnidoscolus phyllacanthus (Müll. Arg.) Pax \& L. Hoffm., Commiphora leptophloeos (Mart.) J.B. Gillett, Croton rhamnifolioides Pax \& K. Hoffm, Guettarda angelica Mart. ex Müll. Arg., Lantana camara L., Maytenus rigida Mart., Opuntia palmadora Mill, Spondias tuberosa Arruda, Rhamnidium elaeocarpum Reissek, Rolliniopsis leptopetala (R.E. Fr.) Saff., Ziziphus joazeiro Mart. and species of Myrtaceae and Rutaceae (SILVA et al., 2009; SILVA et al., 2013).

One hundred $1 \times 1 \mathrm{~m}$ plots were established in the sedimentary area during the middle of the rainy season (March) of 2003. Ten transects were installed $10 \mathrm{~m}$ apart. Along each transect, 10 plots were established at a distance of $5 \mathrm{~m}$, totaling 0,5 ha of sampled area. Of the 100 plots, 27 were located in the center of the island of woody vegetation, 38 at the edge of the island (in a total of 38 islands) and 35 in the open spaces. Due to the systematic distribution of plots, 38 plots were installed at the edges of the islands and 27 plots in the center of the islands. Therefore, not all islands had plots in the center.

Ground-layer herbaceous showed differences in their degrees of lignification and the visibility of their stalks at soil level; they were considered herbaceous if 1) all individuals had non-lignified stalks or stalks with a low level of lignification and color ranging from green to brownish, with or without a trailing habit or 2) the plants that at ground level had aerial system directly represented by the leaves. In the latter cases, the stalks of the herbs were not typically visible above soil level, but when they were visible, they were small, decumbent and rhizomatous. Such a growth habit was recorded only for species of Amaryllidaceae.

In the plot interiors, all herbaceous individuals were counted, marked and measured for stalk height and diameter at soil level. Height was measured with a ruler or measuring tape, and diameter was measured with a digital caliper. All plants unattached to one another at soil level were considered as individuals. For individuals branched at soil level (tillers) without a visible common stalk base, the total diameter of the individual was calculated based on the diameters of all tillers present. For individuals without a visible stalk at soil level but with a leaf (ex. Amaryllidaceae sp.) the bases of the leaves were measured. The height of a plant was measured from the soil level, regardless of whether the plant had a stalk and leaves or only leaves at that point.

The reproductive parts of all flowering herbaceous species in the interior of or near the plots were collected for taxonomic identification. Monthly trips were made to the study areas to collect the flowering parts of species that had been in the vegetative stage during previous samplings.

Because of morphological characteristics exhibited by some species early in their ontogeny, some young herbaceous plants were mistaken as seedlings of woody species. To correct this mistake, individuals of these species were collected, planted in polyethylene containers with soil from the site, transported to the greenhouse at the Universidade Federal Rural de Pernambuco and monitored for six months until reproductive material could be obtained for correct taxonomic identification of the species. A period of six months was established because this was a longer duration than that of the local rainy season, a period during which most herbs complete their life cycles in the caatinga vegetation (ARAÚJO; SILVA; FERRAZ, 2002).

Plant material was herborized following the usual techniques for preparing, drying and assembling exsiccates (MORI; SILVA; LISBOA, 1989). Taxonomic identification was accomplished by comparisons with exsiccates deposited in the herbaria Professor Vasconcelos Sobrinho - PEUFR and Dárdano de Andrade Lima - IPA and with the help of taxonomic keys and specific literature in accordance with APG III. Exsiccates of species with problematic or dubious identification were sent to experts. The spelling of the name of each species and the names of species' authors was checked by Lista de Espécies da Flora do Brasil (http:// floradobrasil.jbrj.gov.br/). After identification, the exsiccates collected by K.A. Silva were incorporated into the herbarium of Professor Vasconcelos Sobrinho - PEUFR, and duplicates were sent to the herbarium of Dárdano de Andrade Lima - IPA.

The Shannon-Wiener diversity index ( $\left.\mathrm{H}^{\prime}\right)$ was calculated. Differences in diversity between the center, edge, and open space areas were verified through Hutcheson's paired t-test $(\mathrm{P}<0.05)(\mathrm{ZAR}$, 1996). The differences in average richness, densities, heights and diameters between the center, edge, and open space areas were checked by the KruskalWallis variance test (ZAR, 1996). Differences in the abundance of each species between the center, edge, 
and open space areas were verified by chi-square test at $5 \%$ probability (ZAR, 1996). The analysis was conducted with the BioEstat 5.0 program (AYRES, 2007).

\section{RESULTS}

The herbaceous flora was represented by 59 species, 51 genera, and 26 families. The families with the largest number of species were Poaceae (seven species), Malvaceae (six) Euphorbiaceae (five), Cleomaceae (four) and Convolvulaceae (four). A total of 51 species were recorded in the center and 55 at the edge of the islands of woody vegetation. In the open spaces, 48 species were recorded (table 1).

Table 1. Abundance of species of herbs found in the center and at the edge of the islands of woody vegetation and in open spaces in an area of caatinga embedded on a sedimentary basin in a semiarid region of the northeast region of Brazil. Column numbers of the areas in the center, edge, and open spaces indicates the abundance of the species. Different letters in the same line between columns indicate significant differences in abundance by the Chi-square test at 5\% probability.

\begin{tabular}{|c|c|c|c|}
\hline \multirow[b]{2}{*}{ Family/species } & \multicolumn{3}{|c|}{ Microhabitats } \\
\hline & Center & Edge & Open Space \\
\hline \multicolumn{4}{|l|}{ AMARANTHACEAE } \\
\hline Alternanthera tenella Colla & $678 \mathrm{a}$ & $428 b$ & $89 \mathrm{c}$ \\
\hline Amaranthus viridis $\mathrm{L}$. & $12 \mathrm{a}$ & $1 b$ & - \\
\hline \multicolumn{4}{|l|}{ AMARYLLIDACEAE } \\
\hline Hippeastrum sp. & $15 \mathrm{a}$ & $23 \mathrm{a}$ & $13 \mathrm{a}$ \\
\hline Indeterminada & $33 \mathrm{a}$ & $2 b$ & $5 b$ \\
\hline \multicolumn{4}{|l|}{ ARISTOLOCHIACEAE } \\
\hline Aristolochia birostris Duch. & $17 \mathrm{a}$ & $9 \mathrm{a}$ & - \\
\hline \multicolumn{4}{|l|}{ ASTERACEAE } \\
\hline Blainvillea acmella (L.) Philipson & $20 \mathrm{a}$ & $2 b$ & - \\
\hline \multicolumn{4}{|l|}{ BORAGINACEAE } \\
\hline Heliotropium angiospermum Murray & 15 & - & - \\
\hline \multicolumn{4}{|l|}{ CACTACEAE } \\
\hline Opuntia inamoena $\mathrm{K}$. Schum. & $9 \mathrm{c}$ & $31 \mathrm{~b}$ & $72 \mathrm{a}$ \\
\hline \multicolumn{4}{|l|}{ CLEOMACEAE } \\
\hline Hemiscola diffusa (Banks ex DC.) Iltis & $24 \mathrm{a}$ & $31 \mathrm{a}$ & $9 \mathrm{~b}$ \\
\hline Physostemon guianense (Aubl.) Malme & $7 \mathrm{a}$ & $11 \mathrm{a}$ & $15 \mathrm{a}$ \\
\hline Physostemon rotundifolium Mart. \& Zucc. & $50 \mathrm{~b}$ & $92 \mathrm{a}$ & $41 \mathrm{~b}$ \\
\hline Dactylaena micrantha Schrad. ex Schult.f & $7 \mathrm{a}$ & $7 \mathrm{a}$ & - \\
\hline \multicolumn{4}{|l|}{ COMMELINACEAE } \\
\hline Callisia repens (Jacq.) L. & $16 \mathrm{a}$ & $1 \mathrm{~b}$ & $1 \mathrm{~b}$ \\
\hline Commelina obliqua Vahl & $50 \mathrm{a}$ & $38 \mathrm{a}$ & $11 \mathrm{~b}$ \\
\hline \multicolumn{4}{|l|}{ CONVOLVULACEAE } \\
\hline Evolvulus frankenioides Moric. & $101 \mathrm{c}$ & $800 \mathrm{a}$ & $700 \mathrm{~b}$ \\
\hline Ipomoea brasiliana (Choisy) Meisn. & $132 \mathrm{a}$ & $104 \mathrm{a}$ & $13 b$ \\
\hline Ipomoea rosea Choisy & $6 a$ & - & $2 \mathrm{a}$ \\
\hline Merremia aegyptia (L.) Urb. & - & - & 2 \\
\hline \multicolumn{4}{|l|}{ CUCURBITACEAE } \\
\hline Ceratosanthes palmata (L.) Urb. & 1 & - & - \\
\hline \multicolumn{4}{|l|}{ CYPERACEAE } \\
\hline Bulbostylis capillaris (L.) C.B.Clark & $2 b$ & $70 \mathrm{a}$ & $91 \mathrm{a}$ \\
\hline Cyperus laxus Lam. & - & $115 \mathrm{a}$ & $105 \mathrm{a}$ \\
\hline
\end{tabular}


Table 1. Continued

\begin{tabular}{|c|c|c|c|}
\hline \multirow[b]{2}{*}{ Family/species } & \multicolumn{3}{|c|}{ Microhabitats } \\
\hline & Center & Edge & Open Space \\
\hline Pycreus lanceolatus (Poir.) C.B.Clarke & - & 13 & - \\
\hline \multicolumn{4}{|l|}{ DIOSCOREACEAE } \\
\hline Dioscorea ovata Vell. & $3 a$ & 1a & $1 \mathrm{a}$ \\
\hline Dioscorea sp. & $3 a$ & 1a & - \\
\hline \multicolumn{4}{|l|}{ EUPHORBIACEAE } \\
\hline Acalypha poiretii Spreng. & $68 \mathrm{a}$ & $1 b$ & $2 \mathrm{~b}$ \\
\hline Astraea lobata (L.) Klotzsch & $2 \mathrm{a}$ & $1 \mathrm{a}$ & $1 \mathrm{a}$ \\
\hline Bernardia sidoides (Klotzch) Müll. Arg. & $40 \mathrm{a}$ & $11 b$ & $6 b$ \\
\hline Euphorbia hyssopifolia L. & $16 \mathrm{a}$ & $5 b$ & $2 \mathrm{~b}$ \\
\hline Microstachys corniculata (Vahl.) Griseb. & - & $2 \mathrm{a}$ & $3 a$ \\
\hline \multicolumn{4}{|l|}{ FABACEAE } \\
\hline Chamaecrista trichopoda (Benth.) Britton \& Rose ex Britton \& Killip & - & $6 a$ & $12 \mathrm{a}$ \\
\hline Zornia brasiliensis Vogel & $10 \mathrm{a}$ & $14 \mathrm{a}$ & $16 \mathrm{a}$ \\
\hline Zornia latifólia Sm. & $1 \mathrm{a}$ & $4 a$ & $8 \mathrm{a}$ \\
\hline \multicolumn{4}{|l|}{ LAMIACEAE } \\
\hline Hypenia salzmannii (Benth.) Harley & $37 \mathrm{a}$ & $38 \mathrm{a}$ & $14 \mathrm{~b}$ \\
\hline Hyptis atrorubens Poit. & $320 b$ & $387 \mathrm{a}$ & $230 \mathrm{c}$ \\
\hline \multicolumn{4}{|l|}{ MALVACEAE } \\
\hline Ayenia erecta Mart. ex K.Schum. & $3 b$ & $11 \mathrm{~b}$ & $28 \mathrm{a}$ \\
\hline Corchorus hirtus L. & $26 \mathrm{a}$ & $2 b$ & $4 b$ \\
\hline Herissantia tiubae (K. Schum.) Brizicky & $45 \mathrm{a}$ & $40 \mathrm{a}$ & $1 b$ \\
\hline Pseudomalacra guianensis (K. Schum.) H. Monteiro & $63 \mathrm{a}$ & $64 \mathrm{a}$ & $13 b$ \\
\hline Sida cordifolia L. & $6 a$ & $3 a$ & $7 \mathrm{a}$ \\
\hline Waltheria rotundifolia Schrank & - & $1 \mathrm{a}$ & $1 \mathrm{a}$ \\
\hline \multicolumn{4}{|l|}{ MOLLUGINACEAE } \\
\hline Mollugo verticillata $\mathrm{L}$. & $354 b$ & $1026 \mathrm{a}$ & $340 b$ \\
\hline \multicolumn{4}{|l|}{ NYCTAGINACEAE } \\
\hline Boerhavia coccinea Mill. & $16 b$ & $35 \mathrm{a}$ & $6 b$ \\
\hline \multicolumn{4}{|l|}{ PHYTOLACCACEAE } \\
\hline Microtea paniculata Moq. & - & 13 & - \\
\hline \multicolumn{4}{|l|}{ PHYLLANTHACEAE } \\
\hline Phyllanthus niruri L. & $542 b$ & $615 \mathrm{a}$ & $79 \mathrm{c}$ \\
\hline \multicolumn{4}{|l|}{ PLANTAGINACEAE } \\
\hline Tetraulacium veroniciforme Turcz. & $3 b$ & $36 \mathrm{a}$ & $6 b$ \\
\hline \multicolumn{4}{|l|}{ POACEAE } \\
\hline Axonopus capillaris (Lam.) Chase & $33 b$ & $38 b$ & $67 \mathrm{a}$ \\
\hline Dactyloctenium aegyptium (L.) Willd. & $30 \mathrm{a}$ & $47 \mathrm{a}$ & $28 b$ \\
\hline Eragrostis acutiflora (Kunth) Nees & $65 \mathrm{a}$ & $7 b$ & $80 \mathrm{a}$ \\
\hline Eragrostis ciliaris (L.) R. Br. & $52 b$ & $206 \mathrm{a}$ & $70 b$ \\
\hline Eragrostis pilosa (L.) P. Beauv. & $8 \mathrm{a}$ & $7 \mathrm{a}$ & $11 \mathrm{a}$ \\
\hline Panicum trichoides Sw. & $285 b$ & $342 \mathrm{a}$ & $93 c$ \\
\hline Tragus berteronianus Schult. & $1 b$ & $6 b$ & $15 \mathrm{a}$ \\
\hline
\end{tabular}


Table 1. Continued

\begin{tabular}{|c|c|c|c|}
\hline \multirow[b]{2}{*}{ Family/species } & \multicolumn{3}{|c|}{ Microhabitats } \\
\hline & Center & Edge & Open Space \\
\hline \multicolumn{4}{|l|}{ PORTULACACEAE } \\
\hline Portulaca halimoides L. & $332 b$ & $581 \mathrm{a}$ & $70 \mathrm{c}$ \\
\hline Portulaca mucronata Link & $107 b$ & $282 \mathrm{a}$ & $48 \mathrm{c}$ \\
\hline Portulaca oleracea L. & $5 \mathrm{a}$ & $1 \mathrm{a}$ & - \\
\hline \multicolumn{4}{|l|}{ RUBIACEAE } \\
\hline Richardia grandiflora (Cham. \& Schltdl.) Steud. & $251 \mathrm{c}$ & $1268 \mathrm{a}$ & $433 b$ \\
\hline Staelia virgata (Link ex Roem. \& Schult.) K.Schum. & $185 \mathrm{c}$ & $1146 \mathrm{a}$ & $926 b$ \\
\hline \multicolumn{4}{|l|}{ SAPINDACEAE } \\
\hline Cardiospermum sp. & $45 \mathrm{a}$ & $6 b$ & $1 b$ \\
\hline \multicolumn{4}{|l|}{ TURNERACEAE } \\
\hline Turnera ulmifolia L. & - & 1 & - \\
\hline
\end{tabular}

The mean richness of the open spaces was significantly lower than the mean richness of the islands. The mean richness of the center and the edge of the islands were similar (table 2).

Table 2. Differences in the density, richness, diameter, and mean height ( \pm standard deviation) of the herbaceous plant community found in the center and at the edge of the islands of woody vegetation, and in the open spaces in an area of caatinga installed in a sedimentary basin in a semiarid region of the northeast region of Brazil. Different letters in the same line between columns indicate significant differences by the Kruskal-Wallis test at $5 \%$ probability.

\begin{tabular}{|c|c|c|c|}
\hline \multirow[b]{2}{*}{ Parameters } & \multicolumn{3}{|c|}{ Microhabitats } \\
\hline & Center & Edge & Open spaces \\
\hline Density (individuals. $\mathrm{m}^{-2}$ ) & $159,7 \pm 87,7 b$ & $211,4 \pm 70,9 \mathrm{a}$ & $108,5 \pm 43,7 \mathrm{c}$ \\
\hline Richness (species.m ${ }^{-2}$ ) & $15,8 \pm 4,0 \mathrm{a}$ & $15,7 \pm 3,6 \mathrm{a}$ & $11,4 \pm 3,3 \mathrm{~b}$ \\
\hline Diameter $(\mathrm{cm})$ & $0,13 \pm 0,11 \mathrm{a}$ & $0,11 \pm 0,07 \mathrm{a}$ & $0,18 \pm 0,25 \mathrm{a}$ \\
\hline Height $(\mathrm{cm})$ & $6,6 \pm 1,8 \mathrm{a}$ & $4,6 \pm 1,6 b$ & $3,8 \pm 1,9 \mathrm{~b}$ \\
\hline
\end{tabular}

The diversity was greater in the center of the islands and decreased significantly at the edge of the islands, and in the open spaces (table 3). Heliotropium angiospermum and Ceratossanthes trifoliata were recorded only in the center of the islands; Pycreus propinquus, Microtea paniculata, and
Turnera ulmifolia only on the edge of the islands; and Merremia aegyptia only in open spaces. Eleven species were found only on the islands (center + edge) and 43 species were common to all three microhabitats.

Table 3. Triangular matrix with the significance of Hutcheson's t-test $(\mathrm{P}<0.05)$ for Shannon's diversity index $\left(\mathrm{H}^{\prime}\right)$ between the center and the edge of the islands of woody vegetation, and open spaces in an area of caatinga installed in a sedimentary basin in a semiarid region of the northeast region of Brazil. $(\mathrm{t}=\mathrm{t}$ calculated by Hutcheson's $\mathrm{t}$-test, $v=$ degrees of freedom. Values in bold highlight the significant difference between the diversity index values).

\begin{tabular}{|c|c|c|c|c|c|}
\hline \multirow[t]{2}{*}{ Microhabitats } & \multirow[b]{2}{*}{$\mathrm{H}^{\prime}$ (nats.ind ${ }^{-1}$ ) } & \multicolumn{2}{|c|}{ Center } & \multicolumn{2}{|c|}{ Edge } \\
\hline & & $\mathrm{t}$ & $v$ & $\mathrm{t}$ & $v$ \\
\hline Center & 2,96 & - & - & - & - \\
\hline Edge & 2,71 & 11,79 & 8131 & - & - \\
\hline Open spaces & 2,61 & 13,12 & 7575 & 4,4 & 6436 \\
\hline
\end{tabular}

The mean density of the herbaceous community was significantly lower in the open spaces than on the islands (table 2). The mean density at the edge of the islands was significantly higher than in the center of the islands (table 2). There was no significant difference in the mean diameter of the community of herbaceous plants between the three microhabitats and the mean height of the individuals was significantly higher in the center of the islands (table 2). Ten species formed more numerous populations in the center of the island; thirteen species formed more numerous populations at the edge of the island, and four species formed more numerous populations in the open spaces (table 1). The remaining species showed no preference for any of the three microhabitats. 


\section{DISCUSSION}

In this study, we found that the islands of perennial vegetation harbor, on average, greater species richness and greater diversity than open spaces, which confirms one of the hypotheses of this study. The phytophysiognomy of warm arid and semiarid regions is extremely diversified (ANDRADE-LIMA, 1981; PUGNAIRE; HAASE; PUIGDEFABREGAS, 1996; FACELLI; TEMBY, 2002; ZHAO et al., 2007). In areas of savannah and shrub forests, for example, perennial plants create a discontinuous cover (FACELLI; TEMBY, 2002; ZHAO et al., 2007). The Physiognomy is similarly to our study area. The canopies of isolated shrubs or shrubbushes alter the conditions of microclimate and soil fertility in the understory and generate a small-scale spatial heterogeneity for the establishment of herbaceous vegetation (MORO et al., 1997b; FACELLI; TEMBY, 2002; ZHAO et al., 2007; TRACOL; GUTIÉRREZ; SQUEO, 2011). Thus, in arid and semiarid regions of high abiotic stress and discontinuous cover, perennials form islands of resources font (MACARTHUR; WILSON, 1967). In the islands, humidity and nutrient availability are greater than in open spaces, hence, the biodiversity of the herbaceous community is higher in the islands (PUGNAIRE; HAASE; PUIGDEFABREGAS, 1996; MORO et al., 1997a; PUGNAIRE; LÁZARO, 2000). Although not measured, we observed that the understory of the islands was shaded, and the ground was wetter and covered with leaf litter. These attributes of the islands of the studied caatinga area may have contributed to the greater richness and diversity around them.

The small-scale heterogeneity of conditions for establishment generated by the islands also plays an important role in the community structure of the herbaceous understory (PUGNAIRE; HAASE; PUIGDEFABREGAS, 1996; MORO et al., 1997a; FACELLI; TEMBY, 2002). In the islands, the accumulation of the leaf-litter is higher than in open spaces (MORO et al.,, 1997a; FULLER, 1999). The higher humidity in the islands accelerates the decomposition rate of organic matter (MORO et al., 1997a). As a result, the soil of the islands has a greater availability of nutrients than that of the open spaces (PUGNAIRE; HAASE; PUIGDEFABREGAS, 1996; FACELLI; TEMBY, 2002; ZHAO et al., 2007). The high fertility of the islands favors the establishment of a herbaceous community with high density, greater biomass and seed production, as well as taller individuals, when compared to the herbaceous community growing in open spaces (PUGNAIRE; HAASE; PUIGDEFABREGAS, 1996; FACELLI; TEMBY, 2002; ZHAO et al., 2007). In this study, we found that the islands have changed the structure of the herbaceous understory community, because $39 \%$ of the species formed more numerous populations in the islands and the mean height and mean density of the herbaceous community was greater in the islands, which confirms the hypothesis of this study.

The literature suggests that light availability is greater on the edge of the islands than in the center (MORO et al., 1997a). In some areas of caatinga, shading can reduce the size of some herbaceous populations, which may reflect on the size and diversity of the community (ARAÚJO-FILHO et al., 2002; SILVA et al., 2009; SILVA et al., 2010). In the islands, the lower density of the community in the center can be justified by shading and this reduction in density can be considered positive. It is likely that the reduction in density has decreased the competition for space and/or resources. Consequently, the distribution of the number of individuals has become more uniform, resulting in a greater diversity and taller individuals in the center.

Thus, although the microclimatic conditions and those of soil fertility were not quantified in the islands and, in the open spaces, we believe in the following hypothetical model: in areas of caatinga vegetation installed on sedimentary basins, with perennial vegetation island physiognomies embedded in a matrix of bare soil, they function as islands of resource font, favoring the establishment of a herbaceous community with greater richness, more diversity, higher density and taller individuals compared to herbaceous plant communities growing in open spaces. Within the islands, the reduction in the availability of light from the edge to the center causes a domino effect: decrease in the density of the herbaceous community, decrease in competition for resources, increased diversity, and greater mean height.

In fact, in regions with warm semiarid climates, the islands promote environmental changes that facilitate the occurrence of herbs beneath their canopies (MACARTHUR; WILSON, 1967; FULLER, 1999; MORO et al.,, 1997b; ZHAO et al., 2007). However, shrubs and/or trees forming the islands may also benefit from the effect of the herbs on the soil (PUGNAIRE; HAASE; PUIGDEFABREGAS, 1996; MORO et al., 1997a). The herbaceous vegetation can protect the soil from erosion, direct sunlight and overheating while maintaining the high moisture content in the islands (PUGNAIRE; HAASE; PUIGDEFABREGAS, 1996; MORO et al., 1997a). Herbs can increase the rate of decomposition of the leaf-litter, because the plant material from the herb community is easier to decompose than the plant material from shrubs and trees (PUGNAIRE; HAASE; PUIGDEFABREGAS, 1996; MORO et al., 1997a). This evidence suggests a mutualistic relationship (PUGNAIRE; HAASE; PUIGDEFABREGAS, 1996). Therefore, although this study has shown that the islands favor the establishment of a herbaceous community with greater richness, diversity, density and height than in open spaces, studies on microclimatic variations, nutrient 
cycling and accumulation of leaf-litter in the islands and in open spaces in consecutive years are needed to better understand the predictive power of these factors on the herbaceous community structure in islands and confirm that the relationship with the shrub-arboreal vegetation is facilitation or mutualism.

Despite harboring a greater richness and diversity, the floristic similarity between the center and the edge of the islands and the open spaces was high. Only two species were unique to the center of the islands, three to the edge of the island, and one to the open spaces. However, if we consider the total number of species in the islands (center and edge), 19\% were unique to the islands. In arid and semiarid regions, the herbaceous species established in islands of resource font can disperse their seeds to open spaces (PUGNAIRE; LÁZARO, 2000; ZHAO et al., 2007). However, the high temperature and low soil moisture in open spaces can compromise the recruitment and establishment of seedlings (PUGNAIRE; LÁZARO, 2000; ZHAO et al., 2007). Thus, despite not having quantified the input and output of seeds in islands and in open spaces, we believe that the islands can function as biodiversity refuges leading to a second hypothetical model: in areas of caatinga, species established in the islands have the ability to disperse their seeds to open spaces, but the high abiotic stress affects the recruitment and establishment of seedlings of some species. The most sensitive species to abiotic stress in open spaces remain in the community protected by the best microclimate conditions and fertility of the islands.

Although speculative, it is also possible that in the event of climate anomalies (e.g., years with rainfall $50 \%$ below average), microclimatic conditions can be so severe that they can lead to the temporal disappearance of the herbaceous community in open spaces. Microclimatic conditions more favorable of the biodiversity refuges (islands) could prevent local extinction of the herbaceous community and, in the future, the islands could function in the system as source of diaspores to the open spaces or smaller island. Therefore, long-term studies on the temporal variation of seed rain, seed bank, dispersal syndromes, resistance of the diaspores, life form of the species and population dynamics are needed to confirm the hypotheses raised in this study.

\section{CONCLUSIONS}

In this study, we found that species richness, diversity, density, and height of the herbaceous community established in islands were higher than in open spaces. Within the islands, the herbaceous community located in the center had greater diversity, greater height, and less density than at the edge. We believe that the woody species that form the islands facilitate the establishment of herbaceous spe- cies in areas of caatinga vegetation installed on sedimentary basins, with perennial vegetation island physiognomy embedded in a matrix of bare soil.

\section{ACKNOWLEDGEMENTS}

The authors acknowledge the experts Afrânio Fernandes, Alexa Araújo, Ana Paula Fortuna Peres, André Laurênio de Melo, Iranildo Melo, Ângela Maria Miranda, Elnatan Bezerra, Jéferson Rodrigues, Josafá Siqueira, José Alves Siqueira, Marcos J. Silva, Maria Bernadete Costa e Silva, Maria de Fátima A. Lucena, Rita Pereira, Roxana Pereira and Suzene Izidio da Silva, who helped with plant identification; the Programa de Pós-Graduação em Botânica da Universidade Federal Rural de Pernambuco; CNPq for granting scholarship support and, especially, Mrs. Maria Elita Ramalho Leal and all her family for receiving us as guests in their home during field research.

\section{REFERENCES}

ANDRADE-LIMA, D. The caatingas dominium. Revista Brasileira de Botânica, São Paulo, v. 4 p. 149-163, 1981.

ARAÚJO-FILHO, J. A. et al. Efeitos da manipulação da vegetação lenhosa sobre a produção e compartimentalização da fitomassa pastável de uma caatinga sucessional. Revista Brasileira de Zootecnia, Viçosa, v. 31, n. 1, p.11-19, 2002.

ARAÚJO, E. L; CASTRO, C. C.; ALBUQUERQUE, U. P. Dynamics of Brazilian Caatinga - A Review Concerning the Plants, Environment and People. Functional ecology and communities, Isleworth, v. 1, n. 1, p. 15-28, 2007.

ARAÚJO, E.L.; SILVA, S.I.; FERRAZ, E.M.N. Herbáceas da caatinga de Pernambuco. In: SILVA, J.M.; TABARELLI, M. Diagnóstico da biodiversidade do estado de Pernambuco. Recife: Sectma, 2002. p.183-206.

AYRES, M. et al. BioEstat - Aplicações estatísticas nas áreas das ciências bio-médicas. Belém, PA, 2007, 364 p.

BEGON, M. ; TOWNSEND, C. R.; HARPER, J. L. Ecologia: de Indivíduos a Ecossistemas. 4. ed. Porto Alegre, RS: ARTMED, 2007. 752 p.

BRASIL: Ministério das Minas e Energia (Projeto Radambrasil). Geologia, geomorfologia, pedologia, vegetação e uso potencial da terra. Ministério das Minas e Energia (Levantamento de Recursos Na- 
turais, 30). Rio de Janeiro, RJ, 1983.

FACELLI, J. M.; TEMBY, A. M. Multiple effects of shrubs on annual plant communities in arid lands of South Australia. Austral Ecology, Adelaide, v. 27, n. 4, p.422-432, 2002.

FIAM/DI, Enciclopédia dos municípios do interior de Pernambuco. Recife, PE, 1986.

FULLER, D. O. Canopy phenology of some mopane and miombo woodlands in eastern Zambia. Global Ecology and Biogeography, Ottawa, v. 8, n. 4, p. 199-209, 1999.

GUREVITCH, J.; SCHEINER, S. M.; FOX, G. A. Competição e outras interações entre plantas. GUREVITCH, J.; SCHEINER, S. M.; FOX, G. A. (Ed.). Ecologia Vegetal. Santa Cecília: ARTMED, 2009, 2.ed., cap. 10, p. 225-256.

MACARTHUR, R.; WILSON, E. O. The strategy of colonization. In: MACARTHUR, R.; WILSON, E. O. (Ed.). Theory of Island Biogeography. Princeton: Princeton University Press, 1967. v. 1, cap. 4, p. 68-93.

MORI, S. A.; SILVA, L. A. M.; LISBOA, G. Manual de manejo do herbário fanerogâmico. Centro de pesquisa do cacau, Ilhéus, 1989.104 p.

MORO, M. J. et al. Effect of the canopy of Retama sphaerocarpa on its understorey in a semiarid environment. Functional Ecology, London, v. 11, n. 4, p. 425-431, 1997a.

MORO, M. J. et al. Mechanisms of interaction between a leguminous shrub and its understorey in a semiarid environment. Ecography, Lund, v. 20, n. 2, p.175-184, $1997 b$.

PERAZZO, G. M. Saneamento urbano e qualidade das águas de pequenas obras hídricas na área de Xingó. Recife, PE: Imprensa Universitária da UFPE, 2002. 264 p.

PUGNAIRE, F. I.; LÁZARO, R. Seed Bank and Understorey Species Composition in a Semiarid Environment: The Effect of Shrub Age and Rainfall. Annals of Botany, Exeter, v. 86, n. 3, p. 807-813, 2000 .

PUGNAIRE, I. P.; HAASE, P.; PUIGDEFABREGAS, J. Facilitation between higher plant species in a semiarid environment. Ecology, Davis, v. 77, n. 5 , p. 1420-1426, 1996.

SAMPAIO, E. V. S. B. Overview of the Brazilian caatinga. In: BULLOCK, S.; MOONEY, H.A.; MEDINA, E. (Ed.). Seasonally dry Tropical Forests.
Cambridge: Cambridge University Press, 1995. v.1, cap. 2, p. 35-58.

SILVA, K. A. et al. Spatial variation in the structure and composition of the herbaceous community in a semiarid region of northeastern Brazil. Brazilian Journal of Biology, São Paulo, v. 73, n. 1, p. 1-14, 2013.

SILVA, K. A.; ARAÚJO, E. L.; FERRAZ, E. M. N. Estudo florístico do componente herbáceo e relação com solos em áreas de caatinga do embasamento cristalino e bacia sedimentar, Petrolândia-PE. Acta Botânica Brasília, São Paulo, v. 23, n. 1, p. 100-110, 2009.

SILVA, K. A. et al. Fatores bióticos e ambientais que afetam a dinâmica de populações herbáceas em diversos tipos vegetacionais do mundo e na caatinga. In: ALBUQUERQUE, U. P.; MOURA, A. N.; ARAÚJO, E. L. (Ed.). Biodiversidade, Potêncial Econômico e Processos Ecológicos em Ecossistemas Nordestinos. Recife: Bauru Canal 6, 2010. v.1, cap. 3, p. 65-95.

TRACOL, Y.; GUTIÉRREZ, J. R.; SQUEO, F. A. Plant Area Index and microclimate underneath shrub species from a Chilean semiarid community. Journal of Arid Environments, Chubut, v. 75, n. 1, p. 1-6, 2011.

ZAR, J. H. Biostatistical analysis. 4.ed. Prentice Hall, Upper Saddle River, 1999, 663 p.

ZHAO, H. L. et al. Shrub facilitation of desert land restoration in the Horqin Sand Land of Inner Mongolia. Ecological Engineering, Naples, v. 3, n. 1, p. 1-8, 2007. 